CORNELL STUDIES IN CIVIL LIBERTY

ROBERT E. CUSHMAN, ADVISORY EDITOR

SECURITY, LOYALTY, AND SCIENCE 



\title{
Security, Loyalty, and Science
}

\author{
$\star$ \\ WALTER GELLHORN \\ PROFESSOR OF LAW IN COLUMBIA UNIVERSITY
}

Cornell University Press

ITHACA, NEW YORK, 1950 
Open access edition funded by the National Endowment for the Humanities/Andrew W. Mellon Foundation Humanities Open Book Program.

Copyright (C) 1950 by Cornell University

First paperback printing 2019

The text of this book is licensed under a Creative Commons Attribution-NonCommercial-NoDerivatives 4.0 International License: https://creativecommons.org/licenses/by-nc-nd/4.0/. To use this book, or parts of this book, in any way not covered by the license, please contact Cornell University Press, Sage House, 512 East State Street, Ithaca, New York 14850. Visit our website at cornellpress.cornell.edu.

Printed in the United States of America

ISBN 978-1-5017-4067-1 (pbk.: alk. paper)

ISBN 978-1-5017-4068-8 (pdf)

ISBN 978-1-5017-4069-5 (epub/mobi)

Librarians: A CIP catalog record for this book is available from the Library of Congress 